\title{
最近の歯学
}

\section{5. 口腔解剖}

ヒトのエナメル質結晶における atomic image

東京医科歯科大学蒾学部解剖学教室 一條 尚, 山下靖雄

健全なとトのエナィル質を材料として, 通常の透過電 子顕微鏡観察標本作製法に従って固定, エポン包理を 行い, いずれも未脱灰の超薄切片を作製, 切片を未処置 のまま透過電子顕微鏡を用いて観察を行った。

電子顕微鏡の観察は日立 $500 \mathrm{H}, 500 \mathrm{~S}, 200 \mathrm{H}$ の各透 過電子顕微鏡を用い, 加速電压 $100 \mathrm{~K} \sim 200 \mathrm{~K} \mathrm{~V}$ で, 結晶 のC軸方向から直接倍率20万〜 70 万で観察を行い, 写真 上で約 1 千万倍に拡大して観察を行った(図 2 )。

エナメル質の結晶を強拡大で観察すると, 図1にみら れるごとく, 径約 $2 \mathrm{~A}$ 微細な粒子状構造が多数出現 し, それらの微細な粒子状構造は六角形を連水た状態で 非常に規則的な配列状態をなしている。

エナメル質の結晶はハイドロキシアパタイトの結晶に
よって構成されていることが今や定説となっている。 そこで多くの研究者によって明確にされているハイド ロキシアパタイトの原子配列模型図を作製し, 透過電子 顕微鏡によって観察された規則的な配列状態をなす微細 な粒子状構造と重ねてみた(図2)。

その結果困 2 にみられるごとく, 電子影徽鏡によって 観察された微細な粒子状構造はハイドロキシアパタイト の原子の配列状態と全く一致することが認められ，それ らのことから微細な粒子状構造はハイドロキシアパタイ トの単位胞に批る columnar Ca（図 2 の○印：C 1 , 3, 5) と $\mathrm{OH}$ の atomic image として出現しているこ とが理解された。
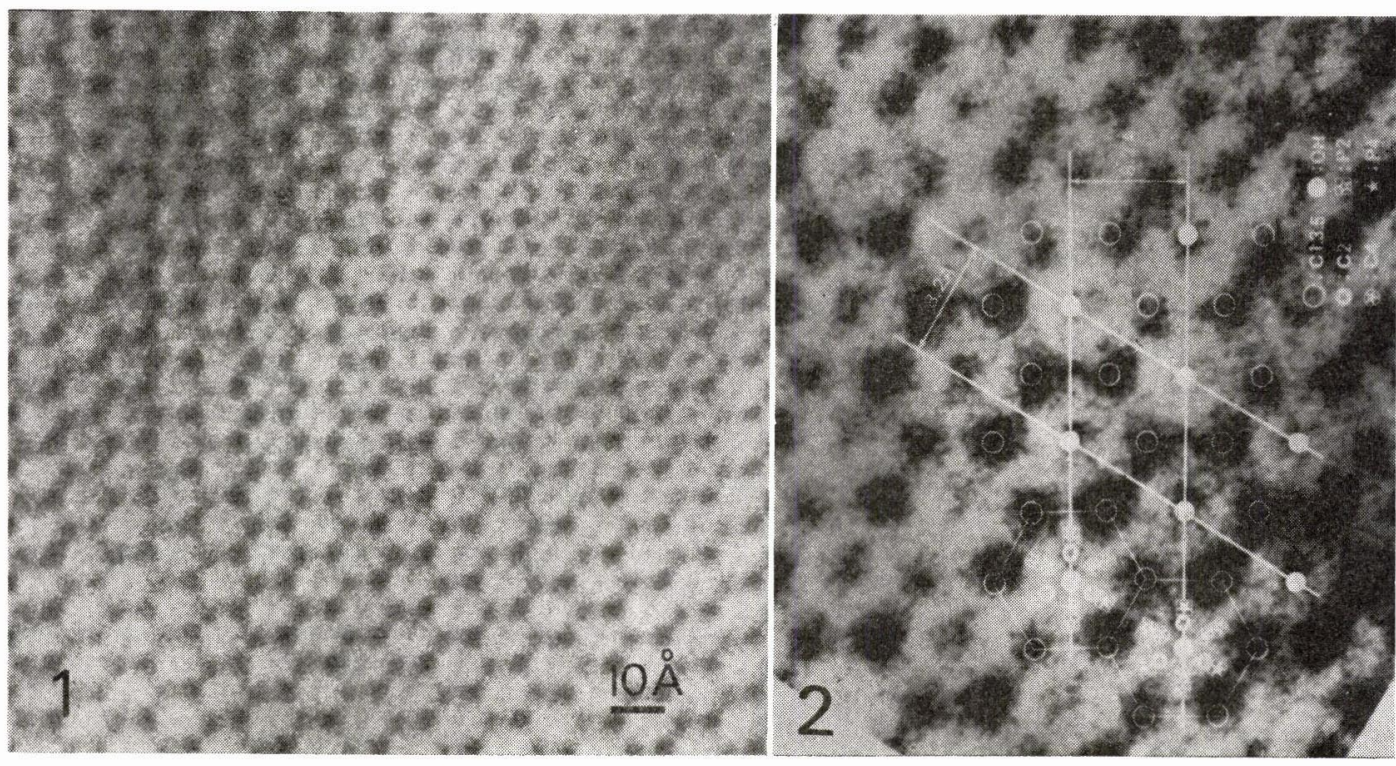